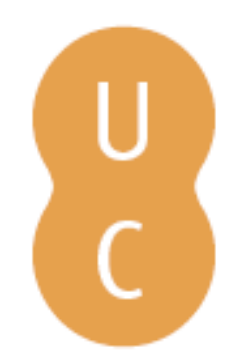

\title{
nommalina
}

\section{Análise da acção e dos saberes de uma equipa de técnicos de um centro de educação e formação de adultos}

Autor(es): Loureiro, Armando

Publicado por: Imprensa da Universidade de Coimbra

URL

persistente: URI:http://hdl.handle.net/10316.2/31239

DOI: $\quad$ DOI:http://dx.doi.org/10.14195/978-989-26-0228-8_7

Accessed : $\quad$ 26-Apr-2023 06:21:14

A navegação consulta e descarregamento dos títulos inseridos nas Bibliotecas Digitais UC Digitalis, UC Pombalina e UC Impactum, pressupõem a aceitação plena e sem reservas dos Termos e Condições de Uso destas Bibliotecas Digitais, disponíveis em https://digitalis.uc.pt/pt-pt/termos.

Conforme exposto nos referidos Termos e Condições de Uso, o descarregamento de títulos de acesso restrito requer uma licença válida de autorização devendo o utilizador aceder ao(s) documento(s) a partir de um endereço de IP da instituição detentora da supramencionada licença.

Ao utilizador é apenas permitido o descarregamento para uso pessoal, pelo que o emprego do(s) título(s) descarregado(s) para outro fim, designadamente comercial, carece de autorização do respetivo autor ou editor da obra.

Na medida em que todas as obras da UC Digitalis se encontram protegidas pelo Código do Direito de Autor e Direitos Conexos e demais legislação aplicável, toda a cópia, parcial ou total, deste documento, nos casos em que é legalmente admitida, deverá conter ou fazer-se acompanhar por este aviso.

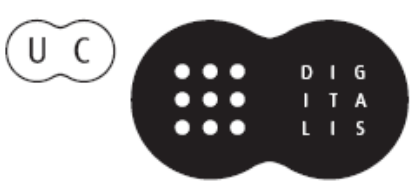




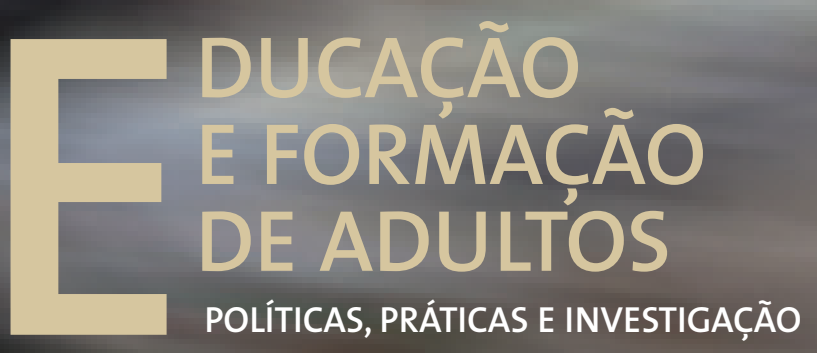

Luís Alcoforado • Joaquim Armando G. Ferreira António Gomes Ferreira • Margarida Pedroso de Lima Cristina Vieira • Albertina L. Oliveira • Sónia Mairos Ferreira 


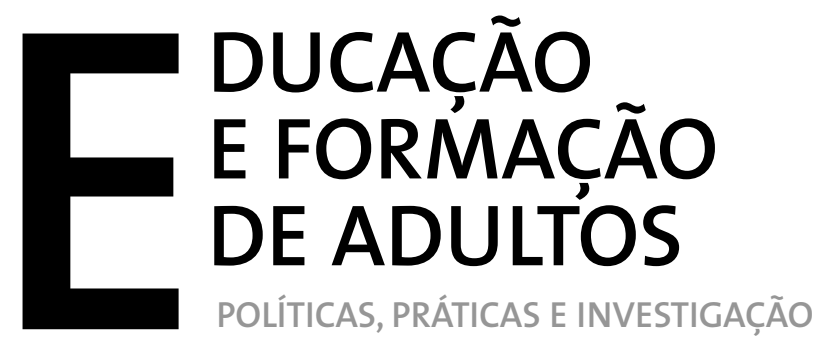

Luís Alcoforado • Joaquim Armando G. Ferreira António Gomes Ferreira - Margarida Pedroso de Lima Cristina Vieira • Albertina L. Oliveira • Sónia Mairos Ferreira 
EDIÇÃo

Imprensa da Universidade de Coimbra

URL: http://www.uc.pt/imprensa_uc

Vendas online: http://www.livrariadaimprensa.com

CONCEPÇÃO GRÁFICA

António Barros

Pré-Impressáo

SerSilito-Empresa Gráfica, Lda

EXECUÇÃo GRÁFICA

SerSilito-Empresa Gráfica, Lda

ISBN

978-989-26-0136-6

DePósito LEgaL

$340309 / 12$ 



\title{
ANÁlise da ACÇÃo E dos SABERES de UMA EQUiPa de téCNICOS de um Centro de Educaçáo e Formação de Adultos
}

\author{
Armando Loureiro \\ Universidade de Trás-os-Montes e Alto Douro
}

\section{Introduçấo}

O campo da Educação de Adultos ganhou em Portugal, na última década, um dinamismo muito forte, fruto de políticas directamente direccionadas para o sector (Loureiro, 2009; Rothes, 2009). Um dos resultados dessa vivacidade foi a afluência cada vez maior de adultos às ofertas educativas entretanto criadas (cursos de Educação e Formação de Adultos - EFA, Centros Novas Oportunidades - CNO...). De acordo com dados da Agência Nacional para a Qualificação (ANQ), desde que os CNO`s foram criados, até 2009 foram mais de 750 mil os adultos a procurá-los (Gaspar, Milagre \& Lima, 2009).

Outro indicador demonstrativo de tal dinamismo é o número cada vez maior e mais diversificado de instituiçóes que têm levado a cabo estas ofertas, bem como o número e a diversidade dos trabalhadores que nelas estão envolvidos. Designaçôes, até há pouco desconhecidas, como Mediadores de cursos EFA, profissionais de Reconhecimento e Validação de Competências (RVC), directores de CNO`s, entre outras, dão conta deste aspecto. Recorrendo novamente aos dados da ANQ, existiam no nosso país, em 2009, mais de 450 CNO's e mais de 7000 técnicos e formadores a trabalharem nestes centros (Gaspar et al., 2009).

O objectivo deste texto é contribuir para que o conhecimento acerca destes novos agentes educativos se vá fazendo. Procura-se concretizar tal finalidade a partir de um estudo etnográfico feito junto de uma equipa de técnicos de um Centro de Educação e Formação de Adultos de uma associaçáo localizada na região do Minho. A escolha desta equipa resultou de uma fase mais extensiva da investigação. $O$ trabalho de campo etnográfico durou seis meses. A recolha dos dados assentou na observação não participante, em conversas informais e na consulta de documentos produzidos no local. O principal instrumento de registo dos dados foi o bloco de notas. Toda a informaçáo recolhida foi transposta para um diário de campo, composto por notas descritivas, metodológicas e empírico-teóricas. Os dados foram triangulados e a técnica de análise de conteúdo foi a eleita para se proceder ao tratamento dos mesmos.

Não se trata de apresentar, aqui, os resultados de todas a dimensóes estudadas nessa investigação, até porque noutros espaços já demos conta de alguns deles, como, por exemplo, os referentes aos usos do discurso pedagógico oficial feito pelos técnicos (Loureiro \& Cristóvão, 2010), às aprendizagens realizadas no e através do trabalho (Loureiro, 2007; 2010a) e às dinâmicas de construção e reconstrução do saber realizadas no seio da equipa técnica (Loureiro, 2010b). Assim, neste momento, dá-se conta apenas das actividades, seus aspectos transversais e das modalidades de saberes identificadas no contexto investigado. Estes resultados vão sendo apresentados, várias vezes, sob a forma de episódios, e vão sendo confrontados com a teoria. 


\section{$O$ contexto e as unidades de análise}

O estudo decorreu, conforme referido acima, num Centro de Educação e Formação de Adultos. O local tem vários espaços (recepção, centro de recursos, salas de formação e salas de reunióes, bar e gabinete técnico). Os técnicos realizam a maior parte das suas actividades no seu gabinete, no entanto também realizam algumas actividades externas. Os principais recursos usados pelos técnicos são o computador, livros e um conjunto de documentos e formulários enviados pelas instituiçóes que enquadram a sua acção.

A equipa era constituída por 6 membros, com idades compreendidas entre os 25 e os 45 anos, 5 dos quais do sexo feminino. Todos eram licenciados na área das Ciências Humanas e Sociais. Possuíam diferentes tipos de vínculo à instituição: voluntariado, contrato a termo, sem termo e trabalho independente. Todos tinham funções técnicas, mas duas das técnicas acumulavam outras funçôes: uma era também da direcção e outra coordenava a equipa.

\section{Actividades e modalidades de saber}

Como foi referido todos tinham actividades técnicas. Estas podem ser divididas em dois grandes momentos: o que antecede a aprovaçáo, feita pelas entidades financiadoras, das acçôes/cursos a realizar e o que se segue a essa aprovação. Do primeiro momento fazem parte os estudos de diagnóstico, o planeamento e a concepção das acçóes/cursos. Do segundo, fazem parte a organização, execução e avaliação das acçóes/cursos.

No decorrer do trabalho de campo foi possível detectar alguns aspectos transversais à sua actividade, ou, dito de outra forma, algumas regras de acção, que se referem a seguir porque foi através delas que muitos dos tipos de saber foram observados e tipificados. Uma dessas regras foi a entreajuda. Efectivamente, apesar de cada técnico ter as suas funçóes e responsabilidades, assistiu-se quase todos os dias a este tipo de trabalho colaborativo, que ia desde a simples realização de um panfleto até ao preenchimento de algum formulário de gestão dos cursos.

A reformulação da prática, do fazer, foi outra regra de acção observada. No seio desta equipa é normal alterar a forma de se fazer e, por vezes, até segmentos que constituem o fazer. Isto resulta, a maior parte das vezes, da detecção de algum tipo de erro ou de uma imperfeição referente à prática. A generalização do fazer, ou seja, a existência de uma forma colectiva de fazer, é outro aspecto transversal à actividade. Por fim, destaque-se a reflexão na e sobre a acção que estes técnicos realizam com muita frequência, seja no decorrer da própria acção, seja em momentos específicos e planeados (reuniôes).

A observação destas regras de acção, e não só, permitiu chegar a muitos dos tipos de saber identificados, dos quais se dá conta a partir deste momento. Do saber contextual da equipa técnica estudada fazem parte dez tipos de saberes, muitos dos quais têm entre si relações fortes, tornando-se, por vezes, difícil conseguir distingui-los: o saber-fazer, o saber dizer, o saber prático, o saber categorial, o saber relacional, o saber estratégico, o saber justificativo, o saber narrativo, o saber conjecturar e o saber declarativo.

O saber-fazer, tal qual é aqui entendido, aproxima-se do "sentido procedimental" do saber de Caria (2003, p. 12). Tal saber remete para o domínio do que, como e quando fazer e de que instrumentos usar para fazer, enfim para o saber desenvolver uma actividade e também para o saber realizar pequenas alteraçóes e adaptaçôes nas rotinas de trabalho. 
Este saber que possibilita produzir instrumentos e meios auxiliares à interacçáo social do qual resultam alteraçóes das rotinas de acção, procurando-se com isso obter maior satisfação local com os resultados das acçóes, procurando-se melhorar a acção. Este tipo de saber não tem a ver com a detecção e correcção de incorrecçóes ou erros face ao que está institucional e externamente prescrito, mas sim face ao que localmente é entendido como uma melhor prática. Portanto, a preocupação é responder a exigências endógenas. As anomalias que possam estar na base das alteraçóes da acção não são controladas nem ditadas pelas entidades externas que regulam a acção dos técnicos.

A conversa tida com uma das técnicas a propósito de um instrumento de trabalho usado para realizarem o processo de RVC dos formandos, mostra a presença deste saber naquele contexto de trabalho.

\section{Episódio - O RVC}

Consultei um dossier de um dos cursos EFA e reparei num instrumento do processo de RVC que não havia visto em consultas anteriormente realizadas relativas a outros cursos. Resolvi perguntar à Joana, a responsável pelo curso em questão, o que era aquele instrumento.

Investigador - Joana, estou aqui a ver este dossier do teu curso de Geriatria e está aqui um material de RVC que não vi nos outros cursos. Este que se refere às expectativas e receios dos formandos, este que tem o título: "reflexão final".

Joana - Bom, isso foi feito numa das sessôes colectivas, já no fim, onde estiveram presentes todos os formadores das áreas da educação de base. Ai é que se fez uma espécie de debate à volta desse tema (...). Foi feito assim, porque se pretendia avaliar questóes ligadas com a oralidade (...). Foi uma forma de tentar obter mais informação que ajudasse no RVC. Os formadores também já tinham lido o dossier do RVC e com esse debate procurou-se tirar algumas dúvidas que os formadores tinham em relação aos formandos.

Investigador - Ah, está bem. E quem fez esse instrumento?

Joana - Fui eu. Algumas questóes foram tiradas de outros instrumentos de RVC que há ai, outras fui eu que as formulei. Depois mostrei à Sílvia e ao Jaime que também me deram sugestóes e foi assim que construi esse instrumento. Eu construi este instrumento porque primeiro os formadores não participavam nestas sessóes colectivas, mas como vimos que a forma como estávamos a fazer o RVC era insuficiente, resolvemos que os formadores passariam a participar e por isso houve a necessidade de criar esta ficha para os ajudar a fazerem a análise de RVC. $E$, foi isso. Nesse curso e nestes deste ano fizemos o RVC de forma diferente. Portanto, antes faziamos todo o RVC e no fim aplicávamos testes, mas verificámos que os formandos ficavam muito constrangidos. Então resolvemos fazer este ano de forma diferente para ver se resultava melhor e portanto náo aplicámos os testes (...) e fizemos nesta sessáo colectiva esse debate com todos os formadores por forma a completarem a informação que já tinham, porque tinham estado noutras sessóes colectivas individualmente e também já tinham lido o dossier. Portanto, tentamos desta forma e penso que resultou melhor...

$\mathrm{Na}$ forma de actuação desta parte do saber-fazer (a que permite introduzir as alteraçôes), está presente um sentido avaliativo da acção. É este sentido avaliativo que leva, várias vezes, a que a alteração do fazer ocorra, procurando-se com isso que a acçáo melhore. 
A presença deste saber mostram-nos que, apesar de toda a normatividade a que está sujeita esta equipa técnica, há espaços criados pelos técnicos, ou não cobertos pelas entidades que orientam a sua acção, que permitem a tal produção de alteraçóes, adaptaçóes na forma de actuar e que, portanto, há espaços de autonomia essenciais ao exercício de um trabalho técnico-intelectual.

O sentido avaliativo da acção também está presente noutro dos saberes identificados: o saber estratégico, que é aquele que leva para o saber quando, porquê e como avaliar determinada acção e também para o para quê da acção efectuada ou a efectuar. Este saber, ao contrário do anterior, remeteu, nos casos observados, para a detecção, interpretação e correcçáo de desajustamentos entre o que se interpreta normativamente e narrativamente sobre o institucionalmente prescrito e o que se obtém ou antecipa vir a obter como resultado da acção. O episódio seguinte remete para uma situação concreta do saber estratégico, mais precisamente para a noção da necessidade de ter que se reavaliar a forma como estavam a fazer uma actividade prescrita.

\section{Episódio - reavaliaçáo de uma actividade}

Estávamos todos no gabinete, excepto a Isabel, e tínhamos decido ir lanchar. Quando nos levantámos para ir ao bar entra a Isabel, cumprimenta-nos apressadamente e diz à Margarida.

Isabel - Margarida, quero falar contigo acerca da situação, acerca de como isto está a correr. Temos que falar, porque eu estive a ler outra vez as orientaçóes e acho que não estamos a trabalhar bem, acho que não estamos a fazer bem a acreditação.

Margarida - Está bem.

Após este breve diálogo a Margarida junta-se a nós e fomos lanchar. Quando regressámos a Isabel já não estava no gabinete. Entretanto, a Margarida, eu e a Joana começámos a conversar sobre os problemas com os formandos e estávamos nisto quando entra a Isabel e passados poucos instantes nos interpela.

Isabel - Já acabaram? - (Já, dissemos os três).

Isabel - Bom, é o seguinte. Nós temos de parar aqui um bocado e vermos o que estamos a fazer e como estamos a fazer a acreditação.

Joana - Eu também acho.

Isabel - Eu estive e ver novamente o guia e acho que não estamos a fazer bem como eles querem e como ainda temos algum tempo escusamos de estar com esta pressa toda a fazer as coisas, senão dá asneira.

Margarida - Pois, é melhor é.

Isabel - Pronto. Então temos de parar um bocado e tornarmos a pensar na maneira como estamos a fazer as coisas, que não me parece a mais correcta (...), por isso temos de marcar uma nova reunião para todos tornarmos a avaliar a situação.

Margarida - Pois, isso é capaz de ser melhor. Às vezes o Jaime, por exemplo, pergunta-me coisas acerca das acçóes para pôr como exemplo de tipos de intervençóes que temos e eu não sei se serão os melhores exemplos. 
Isabel - Pronto, estás a ver? Temos que rever a forma como estamos a trabalhar. Não é só esse aspecto que referiste, mas é também o que se refere àquela parte da formalização das candidaturas, portanto ao como eles querem que se faça.

Joana - Eu também acho que era bom isso dos exemplos ser discutido entre todos para escolhermos os melhores casos e para náo nos andarmos a repetir.

Isabel - Pois, isso também, temos de nos articular melhor. Pronto, temos então que rever tudo isto. Eu ontem, quando cá estive, pareceu-me logo isso. Aliás, falei com a Silvia e ela disse-me que se sentia insegura em relação ao que estava a fazer, que náo tinha a certeza se estaria a fazer de acordo com o que é exigido pelo INOFOR.

(A Sílvia acena com a cabeça, confirmando o que a Isabel acabara de dizer).

Isabel - Pronto, é isso temos de tornar a ver como estamos a fazer...

Outro dos saberes identificados foi o saber prático, que se refere ao saber resolver situaçóes complexas da acçáo (Malglaive, 1995). Este saber leva para a "inteligência das situaçôes" (Cornu, 2003, p. 194). Ela une o sujeito à situação, é um saber em que não há uma justificação do procedimento efectuado, é um saber implícito, em que o actor manifesta uma estratégia implícita que é apenas reconhecida ao nível do relato do feito e não da justificação do ocorrido. É, portanto, um saber em que o actor não desenvolve uma consciência discursiva sobre o que e como fez, em que a justificaçáo do ocorrido se fica, muitas vezes, pelo "vi", "senti que devia fazer assim". O episódio seguinte mostra a presença deste tipo de saber entre os técnicos estudados.

\section{$3^{\circ}$ Episódio - Conflitos entre formandos}

A Sílvia e a Cristina falam acerca de problemas surgidos entre formandos (...).

Sílvia - Sabes, os de Geriatria já se andam a meter com os de Acção Educativa por causa do jantar de Natal.

Cristina - Outra vez (...).

Essa conversa fez-me recordar uma outra do mesmo género a que assisti logo de início. Procurei nos meus registos o seu teor e após terem terminado o diálogo que vinham mantendo dirigi-me à Sílvia.

Investigador - Sílvia, estás muito ocupada?

Sílvia - Não, não estou.

Investigador - Então se não te importas podiamos falar um bocadinho?

Sílvia - Está bem.

Investigador - No dia 25 de Setembro, tu e a Joana falaram das rivalidades entre as formandas. Lembras-te?

Sílvia - Sim, sim, já sei. Isso teve a ver com uma situação que surgiu no cursos de costura, onde há uma formanda que se sobrepóe às outras, tem um nivel muito mais avançado que as outras e as outras, em especial algumas delas não encaram essa situação muito bem e sempre que ela tentava ajudar alguém, ou responder, algumas reagiam muito mal (...). Bom, criou-se um clima um bocado pesado entre elas, foi um problema sério, foi isso. 
Investigador - Sim. E como soubeste dessa situação?

Sílvia - Foram os formadores que me alertaram. Foram eles que pediram para intervir naquela situação de conflito e eu conversei com elas. Portanto, conversei com a tal formanda que sobressai e com as outras que reagiam pior e fiz-lhes ver que essa situação as prejudicava a todas (...). Portanto, tive essa conversa com elas e resultou, o clima melhorou entre elas (...).

Investigador - Sim. Mas, não te importas de dizer como fizeste exactamente? Quer dizer, como as abordaste, como resolveste essa questão?

Sílvia - Bem, eu comecei por falar com a tal formanda que sobressai e comecei por the perguntar como estava a correr o curso. Portanto, não fui logo ao ponto que queria. Ela foi-me falando do curso e eu fui pegando no que ela dizia e depois disse-lhe que tinha ouvido dizer que as colegas não estariam a reagir bem ao facto de ela sobressair e que ela, por sua vez, tinha deixado de tentar ajudar as colegas e ela confirmou-me a situação. Portanto, foi indo de coisas mais gerais até chegar onde queria e ela também me foi contando e depois confirmou-me o que se estava a passar e eu ai, nessa altura, disse-lhe que era uma pena deixar de ajudar as colegas, portanto, nessa altura fui-lhe dando sugestóes. E fiz o mesmo, portanto, usei a mesma estratégia para falar com as colegas e como disse as coisas melhoraram.

Investigador - Ok. E porque resolveste usar essa estratégia?

Sílvia - Bem, não sei. Quer dizer, isso não é nada assim pensado, não é nada planeado, é no momento que decido, vou vendo, quer dizer aquilo é no momento, é ai que vou decidindo como as abordar e isso também depende de como a conversa vai decorrendo. Portanto, foi na altura e isso também tem a ver com a experiência que se tem de outras situaçôes, até de trabalhar com este tipo de público e de situaçóes na Segurança Social, onde trabalhei antes. Mas, quer dizer, não é nada planeado, assim pensado, vou fazer desta ou daquela forma, isso não, nem sei explicar bem porque fiz assim.

Investigador - E já te aconteceu mais vezes esse tipo de situação?

Sílvia - Não, igual não. Há alguns conflitos entre elas e nesses casos mais graves falo com as mais destabilizadoras e uso a mesma estratégia e tem resultado, normalmente as coisas melhoram.

Investigador - Obrigada.

O saber dizer remete para o saber sobre a acção (Terssac, 1996), mais precisamente para o saber explicitar o saber-fazer (o que, como e quando fazer), ou seja, para a explicitação dos segmentos de rotinas e encadeamentos da acção para os pares, o que passa, por exemplo, pelo partilhar determinado instrumento de acção, pelo mostrar e explicar como se usa tal instrumento.

A manifestação deste saber acontece frequentemente quando outro tipo de saber é posto em acção: o saber relacional, isto é, saber-se procurar quem sabe, saber-se procurar quem detém a informação necessária para se agir (Lundvall, 2000), quer essas procuras se efectuem internamente, entre pares portanto, o que nos remete para a dimensáo relacional do saber de que nos fala Charlot (2000) e para a heteroformação (Pineau, 2001), quer essas procuras sejam efectuadas externamente ao local de trabalho, por exemplo junto de técnicos das entidades que regulam os cursos de Educação e Formação de Adultos. Este saber inclui ainda a capacidade de cooperação, nomeadamente de quem é interpelado no sentido de o fazer, ou seja, de quem é interpelado no sentido do saber dizer. Efectivamente, o saber dizer passa também pelo saber dar, partilhar, mostrar o que há para se fazer. $\mathrm{O}$ episódio seguinte dá conta destes dois tipos de saber. Dá conta do saber procurar quem sabe e, simultaneamente, do saber dizer de quem é interpelado. 


\section{4o Episódio - As procuras da Margarida}

A Margarida encontra-se a realizar o "acompanhamento" dos cursos EFA pela primeira vez. Está a preparar uma reuniáo que vai ter em breve com os formadores do curso pelo qual é responsável.

Margarida - Joana, eu precisava de falar contigo ai uns cinco minutos, é sobre a reunião que vou ter com os formadores de Acçâo Educativa.

Joana - Está bem.

Margarida - Queria saber como costumas fazer em relação aos temas de vida. São os formadores que os definem?

Joana - Não, não é assim. Os temas de vida e algumas questóes geradoras são definidas nas aulas pelos alunos e pelos formadores. Eles em conjunto é que decidem (...). Depois, na reunião que tens com os formadores discutes com eles o que eles decidiram, portanto o tema e sobretudo as questôes geradoras, porque muitas vezes não vêm ainda trabalhadas e então é nas reunióes que as questöes sâo acertadas.

Margarida - Ah! Está bem, já percebi. Então vou fazer assim...

$\mathrm{O}$ saber relacional exerce-se, sobretudo, sobre o saber-fazer, ou seja, a maior parte das procuras de saber são feitas sobre este tipo do saber. Entre as dimensóes que este saber tem, a mais procurada foi a do como fazer (uma reunião com os formadores, a selecção de formados, uma acta do júri do processo de RVC, etc.). No entanto, as procuras de o que fazer, do quando, e também de que instrumentos há para fazer, foram procuras igualmente detectadas. Exemplos deste tipo de procuras são as que se referem ao procurar-se saber: que instrumentos de avaliaçáo existem para os cursos EFA, quais estavam a ser usados e em que momentos eram aplicados; ou que instrumentos existem e quais se usavam para se fazer a planificação dos temas de vida dos mesmos cursos. Naturalmente, aconteceu igualmente, por diversas vezes, a procura simultânea de todas aquelas dimensóes do saber-fazer, isto é, quem procurava junto de quem sabe o saber como fazer, também procurava o que deveria fazer, quando e que instrumentos existiam, e como os deveria usar, para fazer.

O saber relacional faz também, embora com menor frequência, com que se manifeste o saber justificativo dos técnicos. Ou seja, quando a interpelação de quem procura um saber vai no sentido de perceber porque se faz de determinada forma (o que se expressa, por exemplo, na questão: “mas porque fazes assim?") e quem responde a tal questáo justifica, explicita o porquê da sua forma de actuação, estamos na presença da parte justificativa do saber, estamos perante o saber porquê da acção realizada.

É também associado ao exercício do saber relacional que, diversas vezes, se manifesta outro tipo de saber, o saber declarativo, muito embora se tenha presenciado a manifestaçáo deste sem que o saber relacional estivesse em acção. O saber declarativo, ao contrário do que é costume na teoria, não se refere, tal como aqui é definido, ao conhecimento de um conceito em abstracto. Ele diz respeito ao saber-se explicitar o que é determinada coisa da acção, seja ela um instrumento de trabalho, uma sigla, ou o próprio entendimento de um conceito sob a perspectiva do actor em contexto de actuação. Ele diz respeito a um saber discursivo que elucida o que é da acção. A diferença relativamente ao saber dizer é que este diz respeito à explicitação do saber-fazer.

Assim, considera-se estar na presença do saber declarativo quando, por exemplo, a propósito da realização do processo de candidatura da acreditação da formação, os técni- 
cos discutiam entre eles o que era a concepçáo dos cursos de educação de adultos, ou o que eram acçōes formativas e acçôes não formativas, pois essa discussão fazia-se a partir da prática, ou seja, a partir do que estavam a fazer naquele momento e das acçóes por eles desenvolvidas que remetiam para aqueles conceitos, e fazia-se, simultaneamente, com base numa interiorização e recontextualização, previamente efectuadas, dos conceitos, que através de tais processos foram interiorizados pelos indivíduos. Quer dizer, para iniciarem e prolongarem a discussão em torno do entendimento tido sobre estes conceitos não tiveram que consultar qualquer documento escrito, ou livro da especialidade, sobre o assunto. Eles já possuíam esse saber e naquela altura explicitaram-no, exteriorizaram um saber que tem uma origem abstracta, mas que eles haviam já inserido no seu reportório de saber.

Também se está na presença deste tipo de saber quando um dos técnicos pergunta a outro, por exemplo, "o que são as questóes geradoras?", "o que são as actividades integradoras?", a propósito da forma como a construção curricular dos cursos EFA é feita, e quem foi interpelado explica o que era, em que consistiam cada uma dessas coisas.

A especificidade da linguagem usada pelos técnicos, a partir da qual todos se entendiam, bastando para tal o uso de uma palavra, ou de uma sigla, sem haver necessidade de explicitação sobre o dito, leva a outro dos saberes identificados: o saber categorial, que anda próximo do sentido categorial-classificatório do saber de Caria (2003). Esta situação verificou-se por diversas vezes, por exemplo quando um dos técnicos dizia aos outros que estava a "lançar o mês", a fazer "os acumulados", a "tratar da planificação", a "preencher o formulário C", a "preencher um GI", ou quando algum deles falava no "RVC", todos sabiam a que procedimento o colega se estava a referir, a que saber-fazer. Portanto, isto quer dizer que este saber pode resumir um procedimento, pode aparecer como uma expressão de um procedimento.

Para além de procedimentos em si, a especificidade da linguagem pode referir-se a instrumentos de trabalho ( "grelhas de RVC"), a cursos (IC - informática para o cidadão), a destinatários dos cursos praticados (DLD - desempregados de longa duraçáo), a filosofias e/ou metodologias específicas de educação de adultos (os EFA, as competências-chave, os temas de vida, os instrumentos de mediação, etc.), entre outros aspectos.

$\mathrm{O}$ apelo ao passado, a acontecimentos passados, à memória colectiva local, ao "nós" feito de experiências individuais que se colectivizam, ou de experiências colectivas desde logo, enfim, o apelo a um reportório colectivo partilhado por todos (Wenger, 2001) que se mobiliza como forma de pensar o presente, como recurso para agir, como forma de comparar o passado e o presente e também como forma de falar do "nós" e dos "outros", diz respeito a outra das modalidades identificada do saber: o saber narrativo. É um saber que é exteriorizado através de relatos sobre aspectos exemplares e marcantes para o grupo e que, por isso, são guias do que localmente é reportório dos saberes do grupo.

Este tipo de saber manifesta-se, diversas vezes, em expressôes como: "vocês lembram-se?", "náo se esqueçam do que aconteceu nos anos anteriores". Ele é activado para falar do "nós" e dos "outros", o que lhes permite fazerem vários tipos de comparaçóes entre o que fazem e como fazem naquele local de trabalho e o que é feito e como é feito noutros locais, e também para falarem e compararem o passado e o presente daquele contexto. Quer num caso, quer noutro, verifica-se a existência de um sentimento de pertença, a existência de uma identidade colectiva, de uma responsabilização dos membros da equipa por aquilo que fazem, de um compromisso colectivo, que leva para algumas das dimensóes do conceito de comunidade de prática de Wenger (2001). O diálogo mantido com alguns dos 
técnicos a propósito do percurso profissional do investigador, levou-os a realizarem esse tipo de referências ao passado e ao presente, a eles e aos outros. De seguida apresenta-se parte desse diálogo.

\section{$5^{\circ}$ Episódio - O passado e o presente, o nós e os outros}

Conversava com os técnicos sobre o meu percurso profissional e parte dessa descrição fê-los recordar a forma como a actividade era desenvolvida inicialmente naquela entidade e fê-los também realizar a comparaçáo da forma como fazem as suas actividades com a forma como é feita noutros locais idênticos.

Investigador - Eu comecei a trabalhar num projecto de luta contra a pobreza ...

Joana - Pois, a associação também começou com um projecto de luta contra a pobreza.

(Acenei com a cabeça de forma afirmativa).

Margarida - Pois foi. Agora o trabalho é um bocado diferente. No inicio passávamos muito tempo no terreno a falar com as pessoas (...). Lembro-me perfeitamente que quando vim à entrevista e me disseram que não queriam técnicos de gabinete. Agora o nosso trabalho é feito essencialmente aqui e isso tem aspectos positivos, mas também tem aspectos negativos, como estarmos mais longe das populaçóes e nós pensamos que isso deve ser alterado e voltarmos a ter um contacto mais directo com a comunidade e vamos voltar a fazê-lo.

(Não interrompo o discurso da Margarida, que de repente começa a fazer outro tipo de comparação).

Margarida - Nós aqui somos responsáveis pela parte pedagógica e também estamos a par da parte da gestão dos cursos. Aqui não é como noutros locais, onde os técnicos só lidam com a parte pedagógica. Nós não, nós temos a responsabilidade das duas partes (...) E isto é importante porque nós sentimos a associação também como nossa, é um pouco parte de nós, das nossas vidas. Nós somos responsáveis por vários aspectos, não é como noutros sítios (...) e essa responsabilidade é-nos incutida desde início (...). Eu penso que isto é muito positivo. Há outras coisas que outros fazem que serão melhores que as nossas, mas nós normalmente estamos atentos a isso e também, se vemos que é benéfico para nós, não temos problemas em introduzir aqui esses aspectos (...).

Este tipo de saber serve, ainda, para recordar acontecimentos passados que todos conhecem e dos quais todos se servem para agir, mas não de uma forma táo visível e tão manifesta como na situação anterior. São acontecimentos que vão sendo referidos algumas vezes entre os técnicos, a maior parte das quais não a propósito de uma qualquer situação concreta que esteja a ocorrer naquele momento, não se vendo por isso um uso manifesto e imediato desse saber passado que foi recordado, mas sim no meio de outros acontecimentos que nada têm a ver, pelo menos aparentemente, com aqueles episódios passados. No entanto, esses acontecimentos passados acompanham permanentemente os técnicos, os quais fazem uso desse saber sem que tenham de o expressar. Trata-se de casos que marcaram profundamente a equipa técnica e dos quais se tiraram liçóes que foram de tal forma interiorizadas que não há uma necessidade de os fazer eclodir/explicitar quando tratam de situaçóes parecidas. Esta dimensão do saber narrativo foi detectada em situações que remetem para zonas problemáticas da acção, normalmente para episódios 
de problemas com formandos, resultando desses episódios passados um saber que faz com que haja um relacionamento tipo por parte dos técnicos relativamente aos formandos. Esse relacionamento a ter é recordado de tempos em tempos, através do recordar das tais situaçóes problemáticas que os levam a saber que atitude ter no presente.

Associado a este saber pode estar outro também registado, o saber conjecturar, ou seja, o ser-se capaz de prever situaçóes futuras, recorrendo-se a experiências passadas que permitem realizar comparaçóes pertinentes para a efectivação desse saber conjectural (Cornu, 2003). No caso deste saber, o recurso à experiência passada não significa sempre o recurso à experiência colectiva da equipa, como acontece no saber narrativo, pode dizer respeito apenas ao recurso a experiências individuais. Também pode acontecer que para além da experiência, o técnico mobilize conhecimento adicional para poder concretizar o saber conjectural.

É este tipo de saber que fez com que, por exemplo, uma das técnicas tivesse começado a tratar de resolver, com muita antecedência, um problema que os seus formandos de um curso (Electricidade de Instalaçôes) lhe colocaram: como ficarem habilitados como técnicos responsáveis de instalaçôes eléctricas? Sabendo que o curso em si não permitia tal habilitação, a técnica em causa começa um processo de busca de informação junto de várias instituiçóes que prevê poderem dar-lhe a resposta pretendida. Após ter conseguido saber que a instituição que poderia resolver a questão seria o Instituto de Emprego e Formação Profissional (IEFP), através da realização de exames teóricos e práticos, a técnica diligencia de imediato no sentido de marcar os referidos exames. Esta sua atitude, ou seja, o tentar tratar desta questáo com antecedência, tem por base experiências passadas que lhe permitem prever, antecipar o que sucederia nesta situação concreta caso não actuasse como o fez. O comentário que a técnica fez, sem que se lhe perguntasse nada, após ter realizado toda a sua busca no sentido de solucionar esta questão vai precisamente no sentido de quem possui este tipo de saber:

“...estava a ver que nunca mais conseguia (...). Sabe? É que estes exames que têm que ser feitos pelo IEFP demoram a ser marcados, demoram muito, por isso é melhor fazer as coisas com tempo para não haver surpresas, para não acontecerem situaçōes como no passado, se não for assim já sei, já estou mesmo a ver o que aconteceria. Nós já sabemos como isto funciona, até já adivinhamos as coisas, por isso é melhor fazer assim..."

Estas foram as modalidades do saber identificadas, que diversas vezes são postas em acção em simultâneo. Como terá ficado entendido, esses saberes podem assumir uma forma implícita ou explícita. O saber prático ou o saber categorial, por exemplo, são casos de saber implícito, o saber relacional, o saber dizer, saber declarativo ou o saber justificativo são exemplos de saberes explícitos. A maior parte desses saberes assume uma forma oral, mas é possível também identificar alguns deles sob a forma escrita em alguns dos documentos produzidos pelos técnicos, por exemplo o saber dizer.

\section{Uma reflexão final}

A análise da acção destes novos actores do campo da Educação de Adultos contribui para um melhor conhecimento acerca deles. Um dos aspectos que pode ser explorado, com 
este tipo de investigaçóes, é tentar-se perceber até que ponto está a ser construída uma certa identidade profissional. Ou seja, não é pelo facto de oficialmente existirem designaçóes como "profissional de RVC" que podemos falar de profissionais.

Sabemos que aqueles que trabalham neste campo não possuem algumas das características consideradas pela sociologia da profissóes como fundamentais para se poder falar de uma profissão, como seja a da formação académica específica para se poder exercer a profissão ou a do reconhecimento social forte. No entanto, há outra forma de entender a profissionalidade, aquela que se constrói através do campo da prática, aquela que assenta num saber que não é constituído apenas por uma racionalidade técnica burocrática, mas que assenta na recontextualizaçáo do conhecimento oficial. Mas não basta reconhecermos que esse saber prático existe, ou se está a construir, é preciso fazer com que ele saia dos locais e se generalize a toda a comunidade de trabalhadores deste campo.

\section{Referências Bibliográficas}

Caria, T. (2003). Os saberes profissionais técnico-intelectuais nas relações entre educação, trabalho e ciência. Proceedings from Midterm Conference Europe 2003, RC 04. Lisboa: International Sociological Association.

Charlot, B. (2000). Da relação com o saber. Porto Alegre: Artmed.

Cornu, R. (2003). Educação, saber e produção. Lisboa: Instituto Piaget.

Gaspar, T., Milagre, C. \& Lima, J. (2009). A sessão de júri de certificação: Momentos, actores, instrumentos - roteiro metodológico. Lisboa: ANQ.

Loureiro, A. (2007). A aprendizagem em local de trabalho: O caso de uma equipa técnica de educação de adultos. Educareducere, 20, 91-107.

Loureiro, A. (2009). O trabalho técnico-intelectual em educação de adultos: Contribuição etnossociológica para a compreensão de uma ocupação educativa. Cascais: Sururu.

Loureiro, A. (2010a). Um centro de educação e formação de adultos que aprende. Educação em Revista, 26 (2), 43-64.

Loureiro, A. (2010b). A dinâmica do saber em local de trabalho: O caso de uma equipa técnica de educação e formação de adultos. Revista Portuguesa de Educação, 23, (2), 93-118.

Loureiro, A. \& Cristóvão, A. (2010). The official knowledge and adult education agents: An ethnographic study of the adult education team of a local development-oriented nongovernmental organization in the north of Portugal. Adult Education Quarterly, 60 (5), 419-437.

Lundvall, B. (2000). L 'économie apprenante et certaines de ses conséquences pour la base de savoir du système de santé et du système éducatif. In AAVV., Société du savoir et gestion des connaissances (pp. 143-162). Paris: OCDE.

Malglaive, G. (1995). Ensinar adultos. Porto: Porto Editora.

Pineau, G. (2001). Experiências de aprendizagem e histórias de vida. In P. Carré e P. Caspar (Dir.), Tratado das ciências e das técnicas da formação (pp. 327-348). Lisboa: Instituto Piaget.

Rothes, L. (2009). Recomposição induzida do campo da educação básica de adultos. Lógicas de apropriação local num contexto politico-institucional redefinido. Lisboa: Fundação Calouste Gulbenkian.

Terssac, G. (1996). Savoirs, compétences et travail. In J-M. Barbier (Dir.), Savoirs théoriques et savoirs d'action (pp. 223-247). Paris: Puf.

Wenger, E. (2001). Comunidades de práctica. Aprendizaje, significado e identidad. Barcelona: Paidós. 
Série Documentos

Imprensa da Universidade de Coimbra

Coimbra University Press

2011

- U

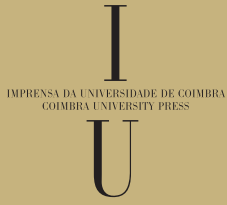

